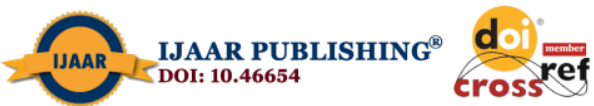

Research Journal of Management Practice | ISSN: 2782-7674

Vol. 7, Issue 3 (March, 2021) | www.ijaar.org

Journal DOI: www.doi.org/10.46654/RJMP

Article DOI: www.doi.org/10.46654/RJMP.7323

\title{
HUMAN RESOURCE ACCOUNTING AND CORPORATE FINANCIAL PERFORMANCE OF QUOTED INSURANCE COMPANIES IN NIGERIA
}

\author{
ONYEKWELU, C. O \\ Department of Accounting, Faculty of Management Sciences, University of Port Harcourt, \\ Port Harcourt. \\ chinelo.okpokwasili@gmail.com
}

IRONKWE, U.I.

Department of Accounting, Faculty of Management Sciences, University of Port Harcourt, Port Harcourt.

\begin{abstract}
The principal aim of our study was to examine the effect of human resource accounting (Human resource accounting disclosure Index, Training cost, Number of staff and Increment in staff salaries) on corporate financial performance (return on assets and return on equity) of insurance companies quoted on Nigeria Stock Exchange for the period 2012 to 2017. Secondary data of 12 quoted insurance companies were collected mostly from their website and the Nigeria Stock Exchange Port Harcourt office. A non-experimental causal (Ex post facto) research design was appropriately adopted to address the research objectives of the study. The lease square regression analysis, precisely the random effect model was used (with the aid of E-views 10) to empirically answer eight research questions raised in the study. The results showed that human resource accounting disclosure and training cost significantly affect Return on Asset and Return on Equity positively while Number of staff and increment in staff salaries has a statistically significant negative effect on Return on Asset. Based on these results, recommendations were given as follows among others, that: Insurance firms should do more in terms of building the culture of capacity building training, developing and motivating the personnel to put in their best for the financial growth of their organizations and enhancing their capacity to improve organizational performance and Insurance firms should increase their human resource accounting disclosure in other to increase stakeholders' confidence in doing business with them thereby improving its performance.
\end{abstract}

Keywords: Human Resources Accounting, Corporate Financial Performance, Insurance Company, Training Cost and Return on Asset. 


\section{Introduction}

Corporate financial performance explains the efficiency or inefficiency of a company. Generally analysts use the past data to arrive at some conclusions about the company. The need to report profit as an initial source for investors' decision-making is well-documented and profit report is helpful in different ways such as presentation of a basis to calculate tax, a measure for assessment of company's performance achievement, a criterion to determine the degree of divisible profits, a criterion to manage the profit distribution, a criterion to manage an economic unit and others that help the economy of the society (Kordestani \& Hedayati, 2011).According to Roger and Wright (1998), performance is probably the most widely used dependent variable in organisational research today, yet it remains one of the most vague and loosely defined constructs. They further confirmed that the struggle to establish a meaning for performance has been ongoing for many years and it is not limited to the field of strategic Human Resource Management (SHRM).According to Okpaki, Atube and Olufawoye (2014), performance of firm measure the percentage of turnover resulting from firm products, return on asset (ROA), return on equity (ROE) and earning per share (EPS).

One of the key contributory factors to an organisational performance is the human resources of an organisation. Human resources play a significant role of coordinating all organisations' activities, towards the achievement of the corporate goals and objectives (Adebawojo, Enyi and Adebawo, 2015). Gavrea, Ilies and Stegerean (2011), confirmed the fact that defining organisational performance has been very challenging to researchers because of its many meanings. However, they traced the history of the attempted definitions of performance as noted by other researchers between 1950s and 2006. Profit figure is one of the critical pointers used to judge the performance of economic units and for this purpose, researchers of financial affairs and accounting have made vast attempts to study the concepts, measurement methods, and the behaviour of accounting profits. Bure as cited in Bakhshani (2015) believes that attention to the concept of accounting profit and its performance scope in company's performance provides a developing ground for empirical investigations of accounting and financial affairs and eventually leads to growth in companies (Saghafi \& Aghaei, 1995). The index of accounting profit is also considered as one of the most important information in economic decision-making and a massive part of the conducted studies in the history of accounting and financial affairs is related to this area of accounting, and presentation of financial reports regarding the outcome of activities of economic firms is defined as sums that are consumable without return of the principal capita (Dornbushc, Rudiger \& Fischer, 1942). Hix (n.d) as cited in Bakhshani (2015) in his definition of profit calls it an amount that the individual could consume during a period of time, while the state of affairs at the beginning of the period is the same as at the end of the period. Alivar (1998) also defines profit as net profit in accounting which is an extra income compared to the costs in a certain period. This extra amount indicates the net increase in shareholders' equities and results from ongoing activities of the commercial unit, minor operation, random developments and other operations and developments together with the effective conditions on the commercial unit which are identified and measured according to the accepted principles of accounting.

Experimental studies have shown that accounting profit has information concept and that is why professional accountants and financial analysts always emphasize on calculating it as far as compliance with the principle of integrating information and using disciplined measurements methods are concerned (Sepehr Duost \& Motiee,2011).Although the initial 
goal of profit reporting is to supply and present useful information for the individuals who make the best of the financial reports, description of more transparent goals including use of profit as a criterion to measure management efficiency, use of historical amounts of profit to anticipate future profit of the economic unit, distribution of dividend and use of profit as a criterion to measure achievements and also a sign of future decisions of the management to grow and develop the company to have a better understanding of profit reporting are necessary (Shabahang, 2007). The following could be regarded as the attributes of organisational performance as identified in Gavrea, Ilies and Stegerean (2011), performance is dynamic, requiring judgment and interpretation; performance may be illustrated by using a casual model that describes how current actions may affect future results; performance may be understood differently depending on the person involved in the assessment of the organisational performance. For instance, performance can be understood differently by a person within the organisation compared to one from outside.

Strikingly, firm performance is the ultimate dependent variable of interest for those concerned with just about any area of management: accounting is concerned with measuring performance; marketing with customer satisfaction and market share; operations management with productivity and cost of operations, organizational behaviour with employee satisfaction and structural efficiency; and finance with capital market response to all the above, management journal, the academy of management journal and administrative science quarterly included some measures of firm performance. The multidimensionality of performance covers the many ways in which organizations can be successful; domain of which is arguably as large as the many ways in which organizations operate and interact with their environment. On the other hand, the model of traditional accounting focuses on financial and physical properties and ignores most of the properties of intellectual capital. Lack of knowledge about human resources accounting and its role in the process of creating value cause the financial statements not to show most of the values for the shareholders and other users (Abbasi \& Sedghi, 2010).

According to Chaturivedi (2013) in Adebawojo, Enyi and Adebawo (2015), the development of human resource accounting originated from the growing needs of the importance of human assets in the management of organisation. It functions as a department that monitors the people that are involved in the organisational resources, as well as monitoring the development, progress in assets and revenues of the company. Hence, assessing corporate performance may not be conclusive without the consideration of the value of human asset.

Human resource is acknowledged as one of the key determinants of corporate performance. Hence, human resource accounting has been the focus of much academic research since the late 1960s. Human Resource is a term which refers to the group of individuals who make up the workforce of an organization or a business entity from top executive down to the hourly labourer. Also human resources are considered by Micah, Ofurum and Ihendinihu (2012) as the energies, skills, talents and knowledge of people which are, or which potentially can be applied to the production of goods or rendering useful services. Human resources accounting is an accounting measurement system, which is actually the process of identifying and measuring data about human resources and communicating this information to interested parties (American Accounting Association's Committee on Human Resource Accounting, 1973). Human resource accounting (HRA) is not a new issue in the field of accounting and economics, and a large body of literature has been published in the last 
decade setting the various procedures for measurement. At the same time the theory and underlying concepts of accounting measurement have received generous attention from academicians and a substantial body of literature has been developed. Under conventional accounting system, human resources are not recognized as physical or financial assets (Mustafizur, Amzad \&Tabassum, 2013). They are not even recognized as intangible assets in the statement of financial position.

There are few international or national standards on how HRA should be applied, hence, its application varies across organizations and countries (Boedker, Mouritsen \& Guthrie, 2008). Some organizations adopt a valuation method suitable for the measurement of their human resources and report such information as additional information or provide supplementary statements in the annual reports. Swedish companies measure and report some of their intangibles such as human resources and intellectual capital according to Swedish models (Asika; Chitom, \& Chelichi, 2017). Large Finnish Companies provide information on training and staff development in their corporate annual reports. While United Kingdom through a business committee of practice referred to as MARIA (Managing and Reporting Intangible Assets) identify value and report on their intangibles. India is one of the countries noted for HRA. Literature provides that a number of entities in both the public and private sectors of India, take interest in monetary valuation of their human resources (Pandey; 2014; \& Orjha, 2013). A number of empirical studies have consequently looked at the relationship between human resource costs and corporate financial performance. Studies in this area include the works of Gaurea., Ilies and Stegerean (2011), Atube and Olufawoye (2014), Adebawojo., Enyi and Adebawo (2015), Asika., Chitom and Chelichi (2017), Nwaiwu and Amos (2018), Nwaiwu and Amah (2020). These empirical studies argue that there is a negative relationship between human resource costs and corporate financial performance, on the other side, the findings of Oluka and Ironkwe (2019).

Tajinder (2019, Nwaiwu (2020) contradict most of the earlier evidence on the effect of human resource costs on corporate financial performance. however, not only did these empirical studies yield conflicting results and conclusions, perhaps due to the methodologies in evaluating their data, but more importantly, the time frame considered in many of them was rather short. Above all, the contexts of these empirical studies were different from Nigeria. This underscores the need for this study. The remainder of this paper is organized as follows after the introduction section II discuss the literature on human resource cost and corporate financial performance. Section III methodology, while empirical results are reported in section IV. Section V concluding remark, recommendations, limitation and suggestion for further studies.

\section{Resource Based Theory}

The prevalence belief among academics and management practitioners is that individual employee performance affects firms' level of outcomes. This means that the contributions of individual employee at various levels of organisation results in corporate goal. For these reason employee's intellectual competence, employee's skill and corporate human resource function, must be properly developed if corporate goals must be achieved. Thus, this position is rooted in Barney (1991), resource based theory of the firm as cited by Bassey and Tapang (2012). The resource based theory indicated that human resource provides a source of sustained competitive advantage which consists of four basic requirements of 
value, rare, imitable and organisation (VRIO) that must be present within the organisation's human resource at all times as discussed below;

Value: Firms create value through either decreasing product or service costs or through product or service differentiation in a way that allows the firm to charge a premium price. Thus the ultimate goal of any human resource (HR) executive is to create value through the human resource function. Therefore, the first question to be addressed by HR executive is how the HR functions can aid in either decreasing costs or increasing revenues. The position of this study is that the solution or answer to this of course could be from the enhancement of corporate intellectual capital through adequate training and development.

Rareness: This postulates that value of a firm's human resources is a necessary but not sufficient criteria for competitive advantage. The reason is that if the same characteristic of human resources is found in many competing firms, then such characteristic cannot be a source of competitive advantage for any one of them. Thus valuable but common characteristics of Human Resource provides only competitive parity, by ensuring that a firm is not at a substantial competitive disadvantage because it does not possess that characteristic. Therefore a Human Resource executive must examine how to develop and exploit rare characteristics of the firm's human resources in order to gain competitive advantage.

Imitation: This explains that the value and the rare characteristics of a firm's human resources can provide above normal profits for the firm in the short term. However, if other firms can imitate the characteristics over time, such characteristic will provide not more than competitive parity. According to Bassey and Tapang (2012), human resources are not subjected to the same degree of imitation as equipment or facilities, investments in firm specific human capital can further decrease the probability of such imitation by qualitatively differentiating a firm's employee from those of its competitors.

Organisation: For any characteristics of a firm's human resource to provide a source of sustained competitive advantage, the firm must be organised to exploit the resource. Organisation requires putting in place the systems and practices that allow human resource characteristics to bear the fruit of their potential advantages. For instance, allowing employees participation in the decision making process could be one of the ways to achieve this, and also allowing them to display their intellectual capabilities in decision making process. Firms' human resources must not be subjected to replacement by substitute if they are to provide a source of sustainable competitive advantage. They further noted that labour-saving technology may limit the returns of some forms of investment in human capital, the continuing shift toward a service economy and the already high levels of automation in many industries make such forms of substitutions increasingly less possible. Therefore, for employees to constitute a source of sustained competitive advantage, they must create value, they must be rare, virtually impossible to imitate and the organisation must create an enabling environment to enable them display their potentials. The resource based theory is considered relevant to this study in that all the human resources characteristics of Value, Imitable, Rareness, and Organisation considered in the theory directly or indirectly affect employee performance which could also influence firms' performance. 


\section{Conceptual Framework}

\section{Corporate Performance}

Generally, performance could be regarded as one of the key determinant factors that are widely used in measuring the success or failure of organisations. Although several research works had been carried out on performance related issues as it affects organisations or firms but its definition has been challenging to researchers. According to Roger and Wright (1998), performance is probably the most widely used dependent variable in organisational research today, yet it remains one of the most vague and loosely defined constructs. They further confirmed that the struggle to establish a meaning for performance has been ongoing for many years and it is not limited to the field of strategic Human Resource Management (SHRM). Gavrea, Ilies and Stegerean (2011), confirmed the fact that defining organisational performance has been very challenging to researchers because of its many meanings. However, they traced the history of the attempted definitions of performance as noted by other researchers between 1950s and 2006. In the 50s organisational performance was defined by Georgopoulos and Tannenbaum (1957) as the extent to which organisations, viewed as social system fulfilled their objectives. In this era, performance evaluation focused on work, people and organisational structures. Between 60s and 70s, organisations explored new ways to evaluate their performance.

\section{Return on Assets}

Return on Assets (ROA): return on assets percentage shows how profitable a company's assets are in generating revenue. ROA is a financial ratio used to measure the degree to which total assets have been used to generate profits. The greater ROA is the better the company's performance, because of the greater rate of return on investment (Riyanto, 2001). The variable ROA, an accounting variable by nature, is the variable most used to measure financial performance (Boaventura, da Silva, Bandeira-de-Mello, 2012). However, ROA should be used with caution because this variable represents short-term performance and does not reflect long-term performance (Boaventura et al., 2012).

\section{Human Resource Accounting (HRA)}

Human resource (HR) is a term used to describe the individuals who comprise the workforce of an organisation, although it is also applied in labour economics to business sectors or even whole nations. Human resource is also the name of the function within an organisation charged with the overall responsibility for implementing strategies and policies relating to the management of individuals (i.e. the human resource). This function title is often abbreviated to the initials 'HR'. Human resources is a relatively modern management term, coined as early as the 1960 s - when humanity took a shift as human rights came to a brighter light during the Vietnam era (Nadler, 1984). The origins of the function arose in organisations that introduced 'welfare management' practices and also in those that adopted the principles of 'scientific management'. From these terms emerged a largely administrative management activity, coordinating a range of worker related processes and becoming known, in time as the 'personnel function'. Human resources progressively became the more usual name for this function, in the first instance in the United States as well as multinational or international corporations, reflecting the adoption of a more quantitative as well as strategic approach to workforce management, demanded by corporate management to gain a competitive advantage, utilising limited skilled and highly skilled workers. 
On the other hand, accounting is viewed as a child of production (Melville, 2009). Production can be either the creation of tangible goods or the provision of services to satisfy human wants. The major factors of production are the land, labour, capital and entrepreneur. While every organisation reports on and includes land, capital and entrepreneur in its financial statements, labour is not given much attention and hence, its expenditure only represents periodic cost made by the organisation. The labour or employees are the human assets or resources organisations have. HRA considers human resource as equivalent to other assets in the organisation. They require investment over time to make them productive. Such investment relates to the hiring, training, and development costs, which are capitalised and amortised over an assumed probably productive life for the human resource, taking into account attrition and eventual deterioration (Young \& Jung, 2003; Myers, 1976). The concept of HRA has been defined in so many ways but the basic feature of the system remains the same in every definition.

The American Accounting Association (1973:23) defined HRA as "the process of identifying, measuring and communicating information about human resource in order to facilitate effective management within an organisation". This definition considers HRA as the process involving recognition and the quantification of human resource for the purpose of assisting the effective management of an organisation. The definition is not specific as to what constitutes the human resource expenditures and how it is to be recognised. A more specific definition of HRA is the one given by Flamholtz (1974), which refers HRA as the process, which involves measuring the cost incurred by business firms and other organisations to recruit, select, hire, train and develop human asset. This gives a view as to what expenditure on the human resource should be recognised for valuation and reporting purposes. This definition, in other words, regards HRA as involving the measurement of economic value of people to organisations. Whereas the above definition of HRA centred on the cost incurred in improving and developing human resource, another definition considers the contributory aspect of human resource. Thus, Friedman and Lev (1974) as well as Lau and Lau (1978) view HRA as a method for systematically measuring both the asset value of labour and the amount of asset creation that can be attributed to personnel activities. This definition incorporates the economic benefit attributable to the human resource in addition to recognising their cost implication.

HRA is also seen as an important aspect of management information system. In this view, Gupta (1991) defines the concept as basically an information system that tells management what changes are occurring overtime to the human resource of the business. It involves accounting for investment in people and their replacement costs, and also the economic value of people in an organisation. This definition regards HRA as an information system capable of assisting the management in effective decision-making relative to the hiring and retention of employees. Therefore, HRA provides a comprehensive look at one method of using human resource cost and value information in the decision-making process. Newman (1999), HRA refers to the measurement of the abilities of all employees of a company, at every level - management, supervisory and ordinary employees - to produce value from their knowledge and the capabilities of their minds. This definition considers the current growth in the service industry where the knowledge and intellectual capabilities of employees are the key elements to success. As such, HRA is seen as the wealth of the employees' knowledge and intellectual capabilities added to the organisation thereby making it to earn profit and to succeed. 
Jasrotia (2004), also views HRA as a measurement and reporting of the cost and value of people as organisational resources. This definition rests on the premise that knowledge and intellectual capabilities of employees are becoming more and more important in corporate investment decision-making. This is due to the fact that service industries are now overtaking the manufacturing industries and in service delivery business, the knowledge and intellectual capabilities of employees matter more than any other tangible asset. Kodwani and Tiwari (2007), HRA is "an attempt to identify, quantify and report investment made in human resources of an organisation that are not presently accounted for under conventional accounting practice". This definition centred on three key areas of human resource: identification of what constitute it, quantification of it in monetary terms, and reporting it in the financial reports of organisation. From the perspective of this definition, human resource is crude in nature, but needs refining in order to determine what constitute HR for accounting purposes. Accounting for human resource entails the capitalisation of investments and other expenditures on employees excluding salaries and wages. However, only investments that can improve the quality and productivity of employees should be capitalised (Jasrotia, 2004; Roslender, 2004; Lev, 2001). But Gates (2002) and Jasrotia (2004) opined that the extent of capitalising the investments on human resource should better be left with the reporting companies. Their argument showed that capitalisation of human resource expenditure is better when a voluntary operational environment is created.

Looking at the trend of definitions in the field of HRA, as highlighted above, this study therefore considers the definition of HRA by Flamholtz (1974) and Jasrotia (2004) as explaining the concept better. This is for the fact that HRA is a combination of cost and value, and does not consider all expenditure on human resource in the capitalization process. In other words, the study views HRA as the measurement process which recognizes cost and value of employees in the financial statements of an organisation, as an intangible asset, to the extent of those expenditure that bring benefit to the organisation for more than one accounting year, so that the true value of the organisation can be established thereby assisting the various users of the financial statements in making their respective decisions.

\section{Empirical Review}

Olayinka and Olayiwola (2017) investigated human resource costs and financial performance using empirical studies evidence from Nigeria using S1 listed manufacturing companies. Secondary data was collected from Central Bank statistical bulletin and Nigerian Stock Exchange. Data collected was analyzed using ordinary least square regression analysis with the aid of statistical package for social sciences version 13 . Findings revealed that the measure of human resource costs exerts a positive and significant effect on corporate earnings, which therefore implies that the capitalization of human resource investment in the annual reports has the propensity to increase corporate earnings.

Young, Sun and Jin (2019 investigated the effect of human resources development on operational and financial performance of manufacturing companies using 207 manufacturing companies at three time points over a five year period. Adopting different statistical analysis, the finding revealed that finial investment and managerial support for HRD had direct effect on operational performance - an recommends that large quoted commercial banks should be mandated to include human resource costs of capital nature in 
their asset while those of revenue in nature should be expensed to enhance quality of information which would impact positively on the share price of the banks. Other match of the webometric studies analyzing the effect, influence, impact, relationship with their authors and year, research title, volume, number and pages are summarized in table 1 below of the investigation of human resource costs and financial performance of quoted banks in Nigeria.

Table 1: Webometric Analysis of Human Resource Accounting and Financial Performance of quoted Insurance companies in Nigeria.

\begin{tabular}{|c|c|c|}
\hline Abubakar, (2009) & $\begin{array}{l}\text { A critique of the concept of } \\
\text { human resource accounting. }\end{array}$ & \begin{tabular}{llr} 
Nigerian & \multicolumn{2}{c}{ Journal of } \\
Accounting & $\&$ & Finance, \\
$1(1), 93-105$ & &
\end{tabular} \\
\hline Abubakar, (2007) & $\begin{array}{l}\text { Human resource investment } \\
\text { and the value of selected } \\
\text { companies quoted on the } \\
\text { Nigerian Stock Exchange. }\end{array}$ & $\begin{array}{lr}\text { Nigerian } & \text { Journal of } \\
\text { Accounting } & \text { Research, } \\
4(2), 39-48 & \end{array}$ \\
\hline Abubakar, (2008) & $\begin{array}{l}\text { Human resource accounting: } \\
\text { An assessment of the } \\
\text { valuation models and } \\
\text { methods. }\end{array}$ & $\begin{array}{lr}\text { Nigerian } & \text { Journal of } \\
\text { Accounting } & \text { Research, } \\
4(2), 80-102 & \end{array}$ \\
\hline $\begin{array}{l}\text { Adebawojo., } \\
\text { Adebawo, (2015) }\end{array}$ & $\begin{array}{l}\text { Human asset accounting and } \\
\text { corporate performance. }\end{array}$ & $\begin{array}{l}\text { American International } \\
\text { Journal of Contemporary } \\
\text { Research, } 5(1), 45-52\end{array}$ \\
\hline $\begin{array}{l}\text { Akindehinde, } \quad \text { Enyi, } \quad \& \\
\text { Olutokumbo, }(2015\end{array}$ & $\begin{array}{l}\text { Human asset accounting and } \\
\text { corporate performance. }\end{array}$ & $\begin{array}{l}\text { American } r \text { International } \\
\text { Journal of Contemporary } \\
\text { Research, 5(1),46-52 }\end{array}$ \\
\hline $\begin{array}{l}\text { Babsay, \& Tapang, (2012) } \\
\text { Bassey }\end{array}$ & $\begin{array}{l}\text { Capitalized human resource } \\
\text { cost and its influence eon } \\
\text { corporate productivity. A } \\
\text { study of selected companies } \\
\text { in Nigeria. }\end{array}$ & $\begin{array}{l}\text { International Journal of } \\
\text { Financial Research, 3(2), 48- } \\
59\end{array}$ \\
\hline Davis, (2018) & $\begin{array}{l}\text { Human resource accounting } \\
\text { and shareholders wealth } \\
\text { maximization: Empirical } \\
\text { study of Nigeria quoted } \\
\text { manufacturing firms. }\end{array}$ & $\begin{array}{l}\text { International Journal of } \\
\text { Business and Management } \\
\text { future, 2(1),45-67. }\end{array}$ \\
\hline $\begin{array}{llll}\text { Edom, } & \text { Inah, } & \text { E.U. } \quad \& \\
\text { Adanma, } & (2015) & \end{array}$ & $\begin{array}{l}\text { The impact of human } \\
\text { resource accounting in the } \\
\text { profitability of a firm. } \\
\text { Empirical evidence from } \\
\text { Assess Bank of Nigeria. }\end{array}$ & $\begin{array}{ll}\text { European } & \text { Journal of } \\
\text { Accounting, Auditing and } \\
\text { Finance Research, 3(7),72-76 }\end{array}$ \\
\hline Ekwe, (2013) & $\begin{array}{l}\text { The relationship between } \\
\text { human capital efficiency and } \\
\text { financial performance: An } \\
\text { empirical investigation of } \\
\text { quoted Nigerian Banks }\end{array}$ & $\begin{array}{l}\text { Research of Journal of } \\
\text { Finance and Accounting. }\end{array}$ \\
\hline $\begin{array}{l}\text { Gaynor, Andrew, Molly, \& } \\
\text { Tari, (2016) }\end{array}$ & $\begin{array}{l}\text { Understanding the relation } \\
\text { between financial reporting }\end{array}$ & $\begin{array}{l}\text { a journal of practice \& } \\
\text { Theory, 35(4),1-22 }\end{array}$ \\
\hline
\end{tabular}




\begin{tabular}{|c|c|c|}
\hline & quality and auditing. & \\
\hline $\begin{array}{l}\text { Geiger, Lennox, \& North, } \\
\text { (2008) }\end{array}$ & $\begin{array}{l}\text { The hiring of accounting and } \\
\text { finance officers from audit } \\
\text { firms: How did the market } \\
\text { react? }\end{array}$ & $\begin{array}{l}\text { Review of accounting } \\
\text { Studies, 13(3),55-86 }\end{array}$ \\
\hline $\begin{array}{l}\text { Ghase Mpour, Yusof, } \\
\text { 2014) }\end{array}$ & $\begin{array}{l}\text { Quality of intellectual } \\
\text { capital and human resource } \\
\text { disclosure on the firm } \\
\text { valuation. }\end{array}$ & $\begin{array}{l}\text { Open Journal of Accounting, } \\
3(5), 59-70\end{array}$ \\
\hline $\begin{array}{l}\text { Ifurueze, Odesa, \& Ifurueze, } \\
\text { (2014) }\end{array}$ & $\begin{array}{l}\text { Impact of aggregated cost of } \\
\text { human resources on } \\
\text { profitability: An empirical } \\
\text { study. }\end{array}$ & $\begin{array}{l}\text { Journal of Business \& } \\
\text { Management, } 3(2), 30-34 .\end{array}$ \\
\hline $\begin{array}{l}\text { Ikpefan, Kzeero, \& Taiwo, } \\
\text { (2015) }\end{array}$ & $\begin{array}{l}\text { Human capital accounting } \\
\text { and performance of } \\
\text { microfinance Bank (MFB) } \\
\text { in Nigeria. }\end{array}$ & $\begin{array}{l}\text { Research Journal of Finance } \\
\text { and Accounting, 6(1),67-75 }\end{array}$ \\
\hline $\begin{array}{l}\text { Human capital accounting: } \\
\text { Assessing possibilities for } \\
\text { domestication of practice in } \\
\text { Nigeria. }\end{array}$ & $\begin{array}{l}\text { Research Journal of Finance } \\
\text { and Accounting, 3(10),57-63 }\end{array}$ & $\begin{array}{l}\text { Research Journal of Finance } \\
\text { and Accounting, 3(10),57-63 }\end{array}$ \\
\hline $\begin{array}{l}\text { Micah, Ofurum, } \quad \& \\
\text { Ihendinihu, (2015) }\end{array}$ & $\begin{array}{l}\text { Firms financial performance } \\
\text { and human resources } \\
\text { accounting disclosure in } \\
\text { Nigeria. }\end{array}$ & $\begin{array}{l}\text { International Journal of } \\
\text { Business and Management, } \\
76(14), 67-75\end{array}$ \\
\hline Obara, (2013) & $\begin{array}{lr}\text { Conventional human asset } \\
\text { accounting } & \text { treatment and } \\
\text { corporate } & \text { profitability } \\
\text { evaluation. }\end{array}$ & $\begin{array}{llr}\text { European } & \text { Journal of } \\
\text { Accounting, } & \text { Auditing and } \\
\text { Finance Research, 1(3),66-80 }\end{array}$ \\
\hline $\begin{array}{l}\text { Odhong, Were, } \\
\text { Omolo,(2014). }\end{array}$ & $\begin{array}{l}\text { Effect of human capital } \\
\text { management drivers on } \\
\text { organizational performance } \\
\text { in Kenya. A case of } \\
\text { investment and mortgages } \\
\text { bank Ltd. }\end{array}$ & $\begin{array}{lr}\text { European } & \text { Journal of } \\
\text { Business } & \text { Management, } \\
2(1), 341-356 & \end{array}$ \\
\hline Okpala, \& Chidi, (2010) & $\begin{array}{l}\text { Human capital accounting } \\
\text { and its relevance to stock } \\
\text { investment decisions in } \\
\text { Nigeria. }\end{array}$ & $\begin{array}{llr}\text { European } & \text { Journal of } \\
\text { Economies, Finance and } \\
\text { Administrative } \\
4(21), 13-18\end{array}$ \\
\hline $\begin{array}{l}\text { Oluwatobi, \& Ogunrinola, } \\
\text { (2011) }\end{array}$ & $\begin{array}{l}\text { Government Expenditure on } \\
\text { Human } \\
\text { Development: Implications } \\
\text { for Economic growth in } \\
\text { Nigeria. }\end{array}$ & $\begin{array}{l}\text { Journal of Sustainable } \\
\text { Development, } 4(3), 72-80\end{array}$ \\
\hline Strauss. (1976) & $\begin{array}{l}\text { Human resource accounting: } \\
\text { Introduction }\end{array}$ & $\begin{array}{l}\text { Journal of Industrial } \\
\text { Relation, } 15(5), 55-69 \\
\end{array}$ \\
\hline Akintoye, (2012) & The relevance of human & International Journal of \\
\hline
\end{tabular}




\begin{tabular}{|c|c|c|}
\hline & $\begin{array}{l}\text { resource accounting to } \\
\text { effective financial reporting. }\end{array}$ & $\begin{array}{l}\text { Business Management and } \\
\text { Econometric Research, 3(4), } \\
566-572\end{array}$ \\
\hline $\begin{array}{l}\text { Asiku., Citom, \& Chelichi, } \\
\text { Chitom (2017) }\end{array}$ & $\begin{array}{l}\text { Appraisal of human resource } \\
\text { accounting on profitability } \\
\text { of corporate organization. }\end{array}$ & Economics, 6(1),1-10 \\
\hline $\begin{array}{l}\text { Avazzadeh Faith, } \quad \& \\
\text { Raiashekar, (2011). }\end{array}$ & $\begin{array}{l}\text { Decision making based on } \\
\text { human resource accounting } \\
\text { information and it evaluation } \\
\text { method. }\end{array}$ & $\begin{array}{l}\text { Asian Journal of Finance and } \\
\text { Accounting, 3(1),14-26 }\end{array}$ \\
\hline $\begin{array}{l}\text { Ijeoma, Bilesammi, \& } \\
\text { Aronu 2000(2013) }\end{array}$ & $\begin{array}{l}\text { Determining the } \\
\text { contribution of human } \\
\text { resource accounting (HRA) } \\
\text { on financial statement of } \\
\text { Nigeria banks using the } \\
\text { mental test analysis. }\end{array}$ & $\begin{array}{l}\text { International Journal of } \\
\text { Scientific \&, Technology } \\
\text { Research, 2(11),51-55. }\end{array}$ \\
\hline $\begin{array}{l}\text { Mclean, Osman, \& Cho, } \\
(2004) .\end{array}$ & $\begin{array}{lrr}\begin{array}{l}\text { Human } \\
\text { development as } \\
\text { policy. }\end{array} & \text { national } \\
\end{array}$ & $\begin{array}{l}\text { Advances in Developing } \\
\text { Human Resource, 6(3),269- } \\
275\end{array}$ \\
\hline Ojha, (2013) & $\begin{array}{l}\text { Prevailing practices of } \\
\text { human resource accounting: } \\
\text { A case study of IT industries } \\
\text { in India. }\end{array}$ & $\begin{array}{l}\text { Journal of Business and } \\
\text { Economics, 4(12),1291-1297 }\end{array}$ \\
\hline Okafor, \& Jeroh, (2010) & $\begin{array}{l}\text { Integrating human capital } \\
\text { concepts in investment } \\
\text { decisions in Nigeria. }\end{array}$ & $\begin{array}{l}\text { Indian Journal of } \\
\text { Multidisciplinary Resource, } \\
6(1), 171-180\end{array}$ \\
\hline Oko, (2018) & $\begin{array}{l}\text { Human asset accounting and } \\
\text { its impact on the } \\
\text { performance and financial } \\
\text { position of firms: A study } \\
\text { of selected companies. }\end{array}$ & $\begin{array}{l}\text { Account and Financial } \\
\text { Management Journal, 3(1), } \\
\text { 1703-1712 }\end{array}$ \\
\hline $\begin{array}{l}\text { Oladele, Aribaba, Ahmodu, } \\
\text { \& Omobola, (2018) }\end{array}$ & $\begin{array}{l}\text { An empirical study of } \\
\text { human resource accounting } \\
\text { disclosure on financial } \\
\text { performance of selected } \\
\text { listed firms in Nigeria. }\end{array}$ & $\begin{array}{l}\text { Journal of Accounting and } \\
\text { Management, } 8(2), 70-82\end{array}$ \\
\hline $\begin{array}{lcc}\text { Okpako, } & \text { Atube, \& } \\
\text { Olufawoye, } & \text { (2014) }\end{array}$ & $\begin{array}{l}\text { Human resource accounting } \\
\text { and firm performance. }\end{array}$ & $\begin{array}{l}\text { Global Journal of Commerce } \\
\& \text { Management Perspective, } \\
\text { 3(4),232-237 }\end{array}$ \\
\hline $\begin{array}{l}\text { Omodero, Alpheaus, \& } \\
\text { Ihendinih, (2016). }\end{array}$ & $\begin{array}{l}\text { Human resource costs and } \\
\text { financial performance of } \\
\text { firms in Nigeria: Evidence } \\
\text { from selected listed firms in } \\
\text { Nigerian. }\end{array}$ & $\begin{array}{l}\text { International Journal of } \\
\text { Interdisciplinary Research } \\
\text { Methods, 3(4),14-27 }\end{array}$ \\
\hline $\begin{array}{l}\text { Omodero, \& Ihendinihu, } \\
(2017) .\end{array}$ & $\begin{array}{l}\text { Human resource accounting } \\
\text { and financial performance of } \\
\text { firms in Nigeria: Evidence }\end{array}$ & $\begin{array}{l}\text { International Journal of } \\
\text { Interdisciplinary Research } \\
\text { Methods, 4(2),25-33 }\end{array}$ \\
\hline
\end{tabular}




\begin{tabular}{|l|l|l|}
\hline \hline & $\begin{array}{l}\text { from selected listed firms in } \\
\text { Nigeria. }\end{array}$ & \\
\hline $\begin{array}{l}\text { Onyinyechi, \& Ihendinihu, } \\
(2017)\end{array}$ & $\begin{array}{l}\text { Human resource accounting } \\
\text { and financial performance of } \\
\text { firms in Nigeria: Evidence } \\
\text { from selected listed firms on } \\
\text { the Nigerian Stock } \\
\text { Exchange. }\end{array}$ & $\begin{array}{l}\text { International Journal of } \\
\text { Interdisciplinary Research } \\
\text { Methods, 3(4), 14-27 }\end{array}$ \\
\hline Paredy, (2014) & $\begin{array}{l}\text { Human resource accounting: } \\
\text { The concept and its practice } \\
\text { in India. }\end{array}$ & $\begin{array}{l}\text { Journal of Management and } \\
\text { Technology, 10(1),29-38 }\end{array}$ \\
\hline Ratti, (2012) & $\begin{array}{l}\text { An analytical study of } \\
\text { human resource accounting } \\
\text { practices - an India } \\
\text { experience integral reviews. }\end{array}$ & $\begin{array}{l}\text { A Journal of Management, } \\
5(2), 37-45\end{array}$ \\
\hline Roslender & $\begin{array}{l}\text { Accounting for intellectual } \\
\text { capital: Rethinking its } \\
\text { theoretical underpinning. }\end{array}$ & Measuring \\
\hline
\end{tabular}

\section{Hypotheses Development}

Ho: : Human Resource Accounting Disclosure (HRAD) will not have significant effect on Return on asset (ROA) of quoted Insurance Companies in Nigeria.

$\mathrm{Ho}_{2}$ : Training cost of staff does not have significant effect on ROA of quoted Insurance Companies in Nigeria.

Ho3: Number of staff will have no significant effect on ROA of quoted Insurance Companies in Nigeria.

Ho⿱ : Increment in staff salary will not have significant effect on Return on asset (ROA) of quoted Insurance Companies in Nigeria.

\section{Methodological Foundation}

This section identified the methodological foundation adopted in evaluating the significant relationship between human resource accounting and financial performance of quoted insurance companies in Nigeria. the research design applied is non-experimental causal research design. D. Chakraborthy Model (Aggregate Payment approach): This model was suggested by Chakraborty in 1976. He has valued the human resources as aggregate and not on an individual basis. He suggested that managerial and non-experimental causal research design and based on data availability, out of 21 quoted insurance companies as available in the Nigerian Stock Exchange website and fact-book only 12 insurance companies were selected as the study sample and a census technique was adopted. Panel data were extracted financial reports and accounts of quoted insurance companies both on Nigerian Stock Exchange and their websites.

We utilized the descriptive statistics for a clear understanding of the various relevant features of the variables, ordinary least square regression analysis, Augmented Dickey Fuller Unit root test, multicollinearity test, and Error Correlation Model used in analyzing the panel data with the aid of E-view package version 10 . 


\section{Model Specification}

The functional relationship between the dependent and independent variable, the disturbance, co-efficient and intercepts for human resources accounting and financial performance for the purpose of the research are stated below:

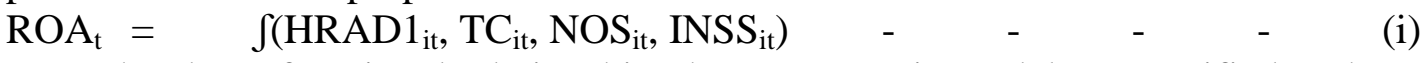

From the above functional relationship, the econometric model are specified as thus:

ROAit $=\quad \beta_{\text {oit }}+\beta_{1}+$ HEADI $_{\text {it }}, \beta_{2} \mathrm{TC}_{\text {it }}+\beta_{3} \mathrm{NOS}_{\mathrm{it}}+\beta_{4}+\mathrm{INSS}_{\mathrm{it}}+\varepsilon_{\mathrm{it}} \quad-\quad$ (ii)

Where: $\mathrm{ROA}_{\mathrm{it}}=$ Return on assets for annual time series of the pooled data -

$\mathrm{HRADI}_{\mathrm{it}}=$ Human resources accounting disclose index $\quad-\quad-\quad$ (iv)

$\mathrm{TC}_{\mathrm{it}}=$ Train Cost accounting disclose index $\quad-\quad{ }^{-} \quad-\quad-\quad$ (v)

NOS $_{\text {it }}=$ Number of staff accounting disclose index $\quad-\quad-\quad$ (vi)

$\mathrm{InSS}_{\mathrm{it}}=\quad$ Increment in staff salary accounting disclose index - $\quad$ (vii)

It $=$ Annual time series of the pooled data.

$\beta_{\text {oit }}=$ Intercepts

$\beta_{1 \text { it }-} \beta_{4 \text { it }}=$ Coefficients slope

$\mu_{\mathrm{it}}=$ Error term

Apriori Expectation

From the foregoing, it is expected that human resource accounting will significantly relate to financial performance. in summary, the apriori expectation is stated as follows:

$\beta_{1 \text { it }}>0, \beta_{2 \text { it }}>0, \beta_{3 i t} .0, \beta_{4 i t}$ respectively.

\section{Empirical Results and Discussion}

The Descriptive statistics which is the summary statistics of both the independent and dependent variables are captured in Table 2. The purpose of the descriptive summary is to enhance understanding of the unique characteristics of the individual variables in the nonlinear regression model. The descriptive statistics captured in Table 2 are the mean, median, standard deviation, skewness, kurtosis and Jarque-Bera, they help to shed light on the data's distribution over the sample period.

\begin{tabular}{|l|c|c|c|c|c|}
\hline \multicolumn{1}{|c|}{ Statistics } & HRADI & NOS & TC & INSS & ROA \\
\hline Mean & 27.27778 & 201.7222 & 3956308. & 28455864 & 0.052914 \\
\hline Median & 22.00000 & 193.0000 & 41731.50 & 743662.5 & 0.030510 \\
\hline Maximum & 50.00000 & 418.0000 & 57404566 & $4.30 \mathrm{E}+08$ & 0.691708 \\
\hline Minimum & 17.00000 & 0.000000 & 0.000000 & 227752.0 & -0.188242 \\
\hline Std. Dev. & 9.002695 & 100.4907 & 13194431 & 94818600 & 0.125223 \\
\hline Skewness & 0.942007 & 0.400395 & 3.141513 & 3.249489 & 3.043937 \\
\hline Kurtosis & 2.862024 & 2.357233 & 11.16469 & 12.07244 & 15.22412 \\
\hline Jarque-Bera & 10.70565 & 3.163243 & 318.4160 & 373.6376 & 559.4742 \\
\hline Probability & 0.004735 & 0.205641 & 0.000000 & 0.000000 & 0.000000 \\
\hline Observations & 72 & 72 & 72 & 72 & 72 \\
\hline
\end{tabular}

The descriptive statistics above provides information on:

Measure of central tendency - mean and median; measures of dispersion - range (the difference between maximum and minimum values) and standard deviation; measures of 
normality - kurtosis (measures the degree of sharpness) and skewness (measures the degree of symmetry).

Multicollinearity Test

Table 3: Inter-Correlation test

\begin{tabular}{|c|c|c|c|c|}
\hline & HRADI & TC & NOS & INSS \\
\hline HRADI & 1.000000 & -0.003156 & -0.181519 & 0.007478 \\
\hline TC & -0.003156 & 1.000000 & 0.005418 & 0.103224 \\
\hline NOS & -0.181519 & 0.005418 & 1.000000 & 0.082517 \\
\hline INSS & 0.007478 & 0.103224 & 0.082517 & 1.000000 \\
\hline
\end{tabular}

The Pearson correlation coefficient between Human resources accounting disclosure index (HRADI) and Training cost (TC), Number of staff (NOS), and Increment in staff salary (INSS) is $-0.003156,-0.181519$, and 0.007478 respectively,indicating a very weak negative correlation between HRADI and TC, HRADI and NOS, and a very weak positive correlation for HRADI with INSS. The correlation coefficient between TC and NOS, and INSS is 0.005418 , and 0.103224 respectively, which shows a very weak positive correlation between TC and NOS, and INSS. The correlation coefficient between NOS and INSS is 0.082517 indicating a very weak positive correlation between NOS and INSS. Overall, these results show clearly that the no multicollinearity condition for regression analysis have been met.

\section{Table 4: Estimated result of Model 1 using Random Effect}

Dependent Variable: ROA

Method: Panel EGLS (Cross-section random effects)

Date: 07/17/19 Time: 13:38

Sample: 20122017

Periods included: 6

Cross-sections included: 12

Total panel (balanced) observations: 72

Swamy and Arora estimator of component variances

\begin{tabular}{|c|c|c|c|c|}
\hline Variable & Coefficient & Std. Error & t-Statistic & Prob. \\
\hline C & 0.116401 & 0.082148 & 4.416969 & 0.0411 \\
\hline HRADI & 0.080187 & 0.001906 & 7.098183 & 0.0221 \\
\hline TC & 8.03E-09 & 0.00E-09 & 5.626334 & 0.0086 \\
\hline NOS & -0.007294 & 0.000237 & -6.238328 & 0.0429 \\
\hline INSS & $-1.05 E-09$ & $0.05 E-10$ & -5.584505 & 0.0178 \\
\hline \multicolumn{5}{|c|}{ Effects Specification } \\
\hline & & & S.D. & Rho \\
\hline \multirow{3}{*}{$\begin{array}{l}\text { Cross-section random } \\
\text { Idiosyncratic random }\end{array}$} & & & 0.078968 & 0.3848 \\
\hline & & & 0.099844 & 0.6152 \\
\hline & \multicolumn{4}{|c|}{ Weighted Statistics } \\
\hline R-squared & 0.702252 & \multicolumn{2}{|c|}{ Mean dependent var } & 0.024270 \\
\hline Adjusted R-squared & 0.606267 & \multicolumn{2}{|c|}{ S.D. dependent var } & 0.101901 \\
\hline S.E. of regression & 0.101581 & \multicolumn{2}{|c|}{ Sum squared resid } & 0.691359 \\
\hline F-statistic & 1.111937 & \multirow{2}{*}{\multicolumn{2}{|c|}{ Durbin-Watson stat }} & 2.048439 \\
\hline Prob(F-statistic) & 0.358266 & & & \\
\hline
\end{tabular}




\begin{tabular}{llll}
\hline \multicolumn{4}{l}{ Unweighted Statistics } \\
\hline \hline R-squared & 0.038085 & Mean dependent var & 0.052914 \\
Sum squared resid & 0.070915 & Durbin-Watson stat & 1.664194 \\
\hline \hline
\end{tabular}

The result of Hausman Test shows that random effect model is more appropriate, this is confirmed by the p-value of 0.1743 . Drawing from this result, this study's Hypothesis one, three, five and seven are tested using random effect model. Having performed this analysis, we proceeded to test the hypotheses formulated in chapter one above to enable us discuss our findings.

\section{Test of Hypotheses:}

$\mathrm{H}_{01}$ : Human Resource Accounting Disclosure (HRAD) will not have significant effect on Return on asset (ROA) of quoted Insurance Companies in Nigeria.

Table 4 shows that Human resource accounting disclosure has a significant positive effect on Return on assets which is one of the proxies of corporate performance in this study (slope $=0.080187, \mathrm{p}$-value $=0.0221$ ). The positive slope of 0.080187 signifies that as Human resource accounting disclosure increases return on assets increases by 0.080187 , and this effect is significant. The p-value of 0.0221 establishes the significance of the effect of Human resource accounting disclosure on return on assets, the value is far less than the 0.05 level set earlier in this study. For that reason, we reject hypothesis one. Our empirical results are in line with the finings of Onyinyechi and Ihendinihu (2017) who invested 10 randomly selected firms from different sector in Nigeria.

$\mathrm{H}_{02}$ : The training cost of staff does not have significant effect on ROA of quoted Insurance Companies in Nigeria.

A look at table 4 shows that training cost of staff has a significant positive effect on return on assets (coefficient $=8.03$, p-value $=0.0086$ ). The positive coefficient of 8.03 shows that as training cost of staff increases return on assets increases by 8.03. The p-value of 0.0086 establishes the significance of the effect of training cost of staff on, the p-value is far less than the 0.05 level. Hence, we reject hypothesis two. The results obtained in however not consistent with the results obtained by a few studies, for example, Prince et al (2013).

Ho3: The number of staff will have no significant effect on ROA of quoted Insurance Companies in Nigeria.

Looking at table 4 shows that number of staff has a significant negative effect on return on assets (coefficient $=-0.007294, \mathrm{p}$-value $=0.0429$ ). The negative coefficient of 0.007294 reveals that a unit increase in the number of staff decreases return on assets by 0.007294 . The p-value of 0.0429 establishes the significance of the effect of the number of staff on return on asset; note that the p-value is far less than the 0.05 level. Therefore, we reject hypothesis three. This empirical results is not in agreement with other empirical results such as that of Izedome et al (2013).

Ho4: Increment in staff salary will not have significant effect on Return on asset (ROA) of quoted Insurance Companies in Nigeria.

Table 4 shows that increment in staff salary has a significant negative effect on return on assets (coefficient $=-1.05, \mathrm{p}$-value $=0.0429$ ). The negative coefficient of 1.05 reveals that a unit increase in staff salary leads to a decrease in return on assets by 1.05 . The p-value of 0.0429 establishes the significance of the effect of the increment in staff salary on return on 
asset, the p-value is far less than the 0.05 level. Therefore, we reject hypothesis four. Our empirical results is in agreement with the works of Bassey and Tapang (2012).

\section{Concluding Remark and Recommendations}

The broad objective of the study is to empirically investigate the relationship between human resource accounting and financial performance of quoted insurance companies in Nigeria. The study adopted the model of Abdeul et al (2014). From the empirical results of the study, we conclude that human resource accounting in companies contribute so much to enhance financial performance of organization.

Based on these, the study recommends that:

(i) Adequate training of staff should be taken into consideration because it will help to expose them to current developments in their area of specialization. Pay for performance incentive will also improve the output of workers because it is a good measure of compensation and it will impact positively on employees and have improve their level of productivity.

(ii) Insurance firms should do more in terms of building the culture of capacity building and training, developing and motivating the personnel to put in their best for the financial growth of their organizations and enhancing their capacity to improve organizational performance.

(iii) Insurance firms should increase their human resource accounting disclosure. In other to increase stakeholders' confidence in doing business with them thereby improving its performance.

\section{Limitation and suggestion for further studies}

An empirical analysis of this magnitude cannot be without limitations with regards to the method which was employed. This empirical analysis list limited to sub variables of human resource accounting (Human resource disclosure index, training cost, number of staff, increment in staff salary) and financial performance (Return on assets) of quoted insurance companies in Nigeria, spanning from 2012-2017. apart from this inherent limitation of being a replication study as already pointed out, this empirical study implies the need for further research, further empirical studies in this area should adopt other variables, spanning from 2000-2021 to enhance the generalability of the research findings and for more robust empirical results.

\section{References}

Abbasi, E. \& Sadghi, A. (2010). The influences of survey of the intellectual capital elements efficiency on the firms financial performance in Tehran Stock Exchange. The Iranian Accounting and Auditing Review, 17(60), 57-74

Abubakar, S. (2007).Human resource investment and the value of selected companies quoted on the Nigerian Stock Exchange. Nigerian Journal of Accounting Research, $4(2), 39-48$

Abubakar, S. (2008).Human resource accounting: An assessment of the valuation models and methods. Nigerian Journal of Accounting Research, 4(2),80-102

Abubakar, S. (2009). critique of the concept of human resource accounting. Nigerian Journal of Accounting \& Finance, 1(1),93-105

Adebawojo., O.E., Enyi, P.E \& Adebawo, O.O. (2015) Human asset accounting and corporate performance. American International Journal of Contemporary Research, $5(1), 45-52$ 
Akindehinde, A.O., Enyi, E.P. \& Olutokumbo, A.O. (2015 Human asset accounting and corporate performance. American International Journal of Contemporary Research, $5(1), 46-52$

Akintoye, I.R (2012). The relevance of human resource accounting to effective financial reporting. International Journal of Business Management and Econometric Research, 3(4), 566-572

Alivar, A. (1998). Fundamental financial statements, $6^{\text {th }}$ Tehran, center for professional accounting and auditing studies. Audit Organisation Publishing (in person).

Asiku,E.R., Citom, J.R. \& Chelichi, I.F (2017). Appraisal of human resource accounting on profitability of corporate organization. Economics, 6(1),1-10

Atube, E.N. \& Olufawoye, O.H. (2014). Human resource accounting and firm performance. Global Journal of Commerce and Management Perspective, 3(4),232-237.

Avazzadeh Faith, F. \& Raiashekar, H. (2011).. Decision making based on human resource accounting information and it evaluation method. Asian Journal of Finance and Accounting, 3(1), 14-26

Babsay, B.E.\& Tapang, A.T (2012).capitalized human resource cost and its influence eon corporate productivity. A study of selected companies in Nigeria. International Journal of Financial Research, 3(2), 48-59

Bakhshani, S. (2015). The relationship between the financial performance and intellectual capital in the food and beverage enterprises. International Journal of Business and Management Review, 3(9), 80-89.

Berney, J.B. (1991). Firm resources and sustained competitive advantage. Journal of Management, 17(1), 99-120

Boedker, C., Moaritsen, J. \& Guthrie, J. (2008). Enhanced business reporting: International trends and possible policy directions. Journal of Human Resource Costing \& Accounting, 12(1), 14-30

Davis, S.A. (2018). Human resource accounting and shareholders wealth maximization: Empirical study of Nigeria quoted manufacturing firms. International Journal of Business and Management future, 2(1),45-67.

Edom, G.O., Inah, E.U. \& Adanma, E. (2015). The impact of human resource accounting in the profitability of a firm. Empirical evidence from Assess Bank of Nigeria. European Journal of Accounting, Auditing and Finance Research, 3(7),72-76

Ekwe, M. (2013). The relationship between human capital efficiency and financial performance: An empirical investigation of quoted Nigerian Banks Research of Journal of Finance and Accounting.

Flamboltz, E.G. (1974). Human resources accounting. California, U.S.A: Dickenson Publishing Company.

Gavrea, C. Ilies, C. \& Stegerean, B. (2011). Determinants of organizational performance. the case study of Romania. Management and Marketing challenges for the knowledge society, 6(2),285-300

Gaynor, M., Andrew, S.K; Molly, M. \& Tari, L.Y. (2016). Understanding the relation between financial reporting quality and auditing. a journal of practice \& Theory, $35(4), 1-22$

Geiger, M., Lennox, C. \& North, D. (2008). The hiring of accounting and finance officers from audit firms: How did the market react? Review of accounting Studies, 13(3),5586

Georopoliclos, B.S. \& Tannenbaum, A.S. (1957). A study of organizational effectiveness. American Sociological Review, 22(3), 534-540 
Ghase Mpour A., Yusof, M.A.A.M( 2014).Quality of intellectual capital and human resource disclosure on the firm valuation. Open Journal of Accounting, 3(5),59-70

Gupta, D.K. (1991). Human resource accounting in India: A perspective. Administrative staff college of India journal of Management, 20(1),9-10

Human capital accounting: Assessing possibilities for domestication of practice in Nigeria. Research Journal of Finance and Accounting, 3(10),57-63

Ifurueze, M.S., Odesa, Y.O. \& Ifurueze, P.C. (2014). Impact of aggregated cost of human resources on profitability: An empirical study. Journal of Business \& Management, $3(2), 30-34$.

Ijeoma, N., Bilesammi, A.O. \& Aronu 2000(2013). Determining the contribution of human resource accounting (HRA) on financial statement of Nigeria banks using the mental test analysis. International Journal of Scientific \&, Technology Research, 2(11),51-55.

Ikpefan, O.A., Kzeero, B.L.O., \& Taiwo, Y.U. (2015). Human capital accounting and performance of microfinance Bank (MFB) in Nigeria. Research Journal of Finance and Accounting, 6(1),67-75

Ironkwe, U.I. (2019). Human resource accounting and firm performance of quoted firms in Nigeria. Accounting journal, 5(2), 35-45

Jasrotia, P. (2004). The need for human resource accounting. Retrieved from http://www.itpeopleindia.com/20021216/cover.shtml.

Kodwami, A.D. \& Tiwar, R. (2007). Human resource accounting - a new dimension. A paper presented at the Cahadian Accounting Association. (CAAA) Annual conference, January.

Kordestani, G.R. \& Hedayati, M. (2011). Accounting benefit; Economic benefit. Certified Public Accountant No. 12(3),118-125

Lamberg, E. (2006). Income measurement: Comments. Accounting Horizon (March) 87101

Lev, B. (2001). Intangibles: Management, measurement and reporting Washington, D.C Brooking Institution Press.

Mclean, G.N., Osman Gani, A.M. \& Cho, E(2004).. Human resource development as national policy. Advances in Developing Human Resource, 6(3),269-275

Melville, A. (2009). International Financial Reporting. London: Pearson Education.

Micah, L.C., Ofurum, C.O. \& Ihendinihu, J.U. (2015).Firms financial performance and human resources accounting disclosure in Nigeria. International Journal of Business and Management, 76(14), 67-75

Mustafizur, R. Amzad, H \& Tabassum, A (2013). Problem with human resource accounting and a possible solution. Research Journal of Finance and Accounting. 4(18),1-10

Myers, C.A (1976). Huamn resource accounting. Monthly Labour Review, 99(4),25-42

Newman, B.H (1999). Accounting recognition of human capital assets. New York: Pace university press.

Nodler, L. (1984). The handbook of human resources development. New York: John Wiley and Sons.

Nwaiwu, J.N. \& Amah, A.C. (2020). Human resource accounting. Financial Analysts journal, 3(1), 69-78

Nwaiwu, J.N. \& Amos, C.A. (2018). Audit control and financial performance in Nigeria: Journal of accounting and Finance, 12(2),32-45

Obara, L.C. (2013). Conventional human asset accounting treatment and corporate profitability evaluation. European Journal of Accounting, Auditing and Finance Research, 1(3),66-80 
Odhong, A.E., Were, A. \& Omolo, Y. (2014).. Effect of human capital management drivers on organizational performance in Kenya. A case of investment and mortgages bank Ltd. European Journal of Business Management, 2(1),341-356

Ojha, S. (2013). Prevailing practices of human resource accounting: A case study of IT industries in India. Journal of Business and Economics, 4(12),1291-1297

Okafor, C. \& Jeroh, E. (2010). Integrating human capital concepts in investment decisions in Nigeria. Indian Journal of Multidisciplinary Resource, 6(1),171-180

Oko, S.U. (2018). Human asset accounting and its impact on the performance and financial position of firms: A study of selected companies. Account and Financial Management Journal, 3(1), 1703-1712

Okpako, P.O., Atube, F.N. \& Olufawoye, O.H. (2014). Human resource accounting and firm performance. Global Journal of Commerce \& Management Perspective, 3(4), 232-237

Okpala, P.O. \& Chidi, O.C. (2010). Human capital accounting and its relevance to stock investment decisions in Nigeria. European Journal of Economies, Finance and Administrative Sciences, 4(21), 13-18

Oladele, P.O., Aribaba, F.O. Ahmodu, O.L. \& Omobola, M.A. (2018). An empirical study of human resource accounting disclosure on financial performance of selected listed firms in Nigeria. Journal of Accounting and Management, 8(2),70-82

Oluwatobi, S.O. \& Ogunrinola, 0.1. (2011). Government Expenditure on Human Capital Development: Implications for Economic growth in Nigeria. Journal of Sustainable Development, 4(3),72-80

Omodero, C.O. \& Ihendinihu, J.U (2017).. Human resource accounting and financial performance of firms in Nigeria: Evidence from selected listed firms in Nigeria. International Journal of Interdisciplinary Research Methods, 4(2), 25-33

Omodero, C.O. \& Ihendinihu, J.U. (2017). HRA and financial performance of firms in Nigeria: Evidence from selected listed firms in Nigeria. International Journal of Interdisciplinary Research Methods, 3(4),14-24.

Omodero, C.O. Alpheaus, O. E \& Ihendinih, J.U (2016).. Human resource costs and financial performance of firms in Nigeria: Evidence from selected listed firms in Nigerian. International Journal of Interdisciplinary Research Methods, 3(4), 14-27

Onyinyechi, O.C \& Ihendinihu, J.U. (2017). Human resource accounting and financial performance of firms in Nigeria: Evidence from selected listed firms on the Nigeria Stock Exchange. International Journal of Interdisciplinary Research methods, 2(3), 25-33

Onyinyechi, O.C. \& Ihendinihu, J.U (2017). Human resource accounting and financial performance of firms in Nigeria: Evidence from selected listed firms on the Nigerian Stock Exchange. International Journal of Interdisciplinary Research Methods, 3(4),1427

Pandey, N. (2014). Human resource accounting: The concept and its practice in India. Journal of Management and Technology, 10(10),29-38

Paredy, N. (2014). Human resource accounting: The concept and its practice in India. Journal of Management and Technology, 10(1),29-38

Prince, F.I., Luckey, G.O. \& Kingsley, K. (2013). Human resource accounting and its impact on organizational performance. Journal of Economics and Sustainable Development, 4(15),125-152

Ratti, M. (2012). An analytical study of human resource accounting practices - an India experience integral reviews. A Journal of Management, 5(2),37-45. 
Ratti, M. (2012). An analytical study of human resource accounting practice - an India experience integral review. A Journal of Management, 5(2),37-45

Roslender, R. (2004). Accounting for intellectual capital: Rethinking its theoretical underpinnings. Measuring Business Excellence, 8(1),38-45

Roslender` Accounting for intellectual capital: Rethinking its theoretical underpinning. Measuring Business Excellence, 8(1),38-45

Saghofi, A. Aghael, M.B (1942). Behaviour of accounting earnings. The Iranian Accounting Review, 3(9), 5-21.

Sepeher, Duost, H. \& Motiee,B. (2011). The role of intellectual capital in the performance of Tehra.

Shahahavg, R. (2007). Accounting theory, center for professional accounting and auditing. Studies audit organization, $4^{\text {th }} \mathrm{Ed}, 161-167$

Strauss. G (1976).Human resource accounting: Introduction Journal of Industrial Relation, 15(5),55-69

Tang, T. (2005). Human resource accounting as a management tool. Human resource Management Journal, 14(2), 75-90

Verma, S. \& Dewe, P. (2004). Measuring the value of human resource. Accounting and Business, 38(4), 46-48 